\title{
Lócus de enunciação e coletivo mexicano Batallones Femeninos: cartografando uma pedagogia decolonial no Sul Global
}

Lívia Márcia Tiba Rádis Baptista ${ }^{\text {(D) }}$

\section{RESUMO}

Neste texto, a partir de uma perspectiva decolonial (BALLESTRIN, 2013; BERNARDINO-COSTA; MALDONADO TORRES; GROSFOGUEL, 2019) e consoante com as epistemologias do Sul (SANTOS, 2019; 2010; 1995; MENESES, 2008), defendemos o lócus de enunciação (BERNARDINOCOSTA; GROSFOGUEL, 2016; FIGUEIREDO; GROSFOGUEL, 2010; GROSFOGUEL, 2006; 2010) como crucial para a definição de práticas e atitudes decoloniais. Neste sentido, argumentamos que o lócus de enunciação materializa uma práxis contrária à ordem hegemônica estabelecida, tornando-se um espaço de práticas e ações que impulsionam pedagogias decoloniais (WALSH, 2013; MOTA NETO; STRECK, 2019). Em primeiro lugar, apresentamos nosso entendimento acerca do lócus de enunciação, enfatizando-o como um espaço catalizador e potencializador de discursos e práticas de linguagem que reconfiguram o espaço enunciativo do Sul Global com reverberações sob a forma de práticas decoloniais. Posteriormente, tornamos

\section{Como citar:}


mais visíveis as práticas de linguagem que se projetam desde o lócus enunciativo, particularizando o cenário da fronteira Norte do México e, em concreto, o coletivo Batallones Femeninos que, por meio de um conjunto de práticas de linguagem disseminadas em mídias diversas, fazem frente as múltiplas colonialidades do ser, poder e saber (QUIJANO, 2005).

Palavras-chave: Decolonialidade. Pedagogia decolonial. Lócus de enunciação. Fronteira Norte. Feminismos.

\section{Considerações iniciais}

Neste texto, a partir de uma perspectiva decolonial (BALLESTRIN, 2013; BERNARDINO-COSTA; MALDONADO TORRES; GROSFOGUEL, 2019) e sintonizada com as epistemologias do Sul (SANTOS, 2019; 2010; 1995; MENESES, 2008), propomos o lócus de enunciação (BERNARDINOCOSTA; GROSFOGUEL, 2016; FIGUEIREDO; GROSFOGUEL, 2010; GROSFOGUEL, 2006; 2010) como crucial para a definição de práticas decoloniais de sujeitos contrapostas à colonialidade e desenho de outras cartografias no Sul Global.

Antes de prosseguirmos em nossas considerações, esclarecemos que, conforme Bernardino-Costa, Maldonado Torres e Grosfoguel (2019, p.6), a decolonialidade pode ser entendida em sentido restrito, tal como elaborado pelo grupo da modernidade/colonialidade. Porém, ademais dessa concepção os autores se referem a um sentido amplo que abarca a longa luta de resistência das populações negra e indígena. Sendo assim, para os autores supracitados "uma das vantagens do projeto acadêmico-político da decolonialidade reside na sua capacidade de esclarecer e sistematizar o que está em jogo, elucidando historicamente a colonialidade do poder, do ser e do saber e nos ajudando a pensar em estratégias para transformar a realidade". Desse modo, neste trabalho nos aproximamos desse entendimento quanto à decolonialidade. Ademais disso, compartilhamos do proposto por Santos (2019, p. 18), com relação às epistemologias do Sul, no sentido de que essas "[...] referem-se aos conhecimentos que surgem das lutas sociais e políticas e não podem ser separados dessas mesmas lutas. 
Não se trata, por conseguinte, de epistemologias no sentido convencional do termo. [...]". Assim sendo, como observa o mesmo autor, "as epistemologias do Sul ocupam o conceito de epistemologia para o ressignificarem enquanto instrumento de interrupção das políticas dominantes e dos conhecimentos que as sustentam. São epistemologias experienciais".

Seguindo em nossas considerações, acreditamos que o lócus de enunciação (BERNARDINO-COSTA; GROSFOGUEL, 2016; FIGUEIREDO; GROSFOGUEL, 2010; GROSFOGUEL, 2006; 2010), como um potente dispositivo, materializa uma práxis contrária à ordem hegemônica estabelecida ao viabilizar um conjunto de práticas e ações que impulsionam pedagogias decoloniais (WALSH, 2013; MOTA NETO; STRECK, 2019). Entendemos que, ao ocuparem esse espaço de enunciação, os sujeitos tensionam os processos e as condições de subalternização impostas, fazendo emergir formas-outras de subjetividade, opostas à lógica da modernidade/colonialidade GÓMEZ QUINTERO, 2010; CASTRO GÓMEZ, 2007; MIGNOLO, 2011), sobretudo, no que se referem às dimensões da colonialidade do ser, poder e saber (QUIJANO, 2005). Sendo assim, ao longo deste texto, visamos contribuir para uma reavaliação da ideia de lócus de enunciação, enquanto um dispositivo por meio do qual os sujeitos subalternizados historicamente ocupam um espaço na discursividade em curso, demarcando tanto um pensar decolonial, quanto um fazer, ou seja, uma práxis decolonial. Com essa finalidade, particularizamos o coletivo mexicano Batallones Femeninos que propõe e difunde práticas decoloniais relacionadas à sua produção musical, artística e sua performance, bem como contribui para a divulgação de outras práticas em sua rede social, de maneira que essa pedagogia se espraia, amplificando seu alcance.

Quanto à organização deste trabalho, em um primeiro momento, explicitamos nosso entendimento a respeito do lócus de enunciação, qual seja, como um espaço catalizador e potencializador de discursos e práticas de linguagem que, sob a forma de práxis decoloniais, reconfiguram o espaço enunciativo do Sul Global, um território geopolítico complexo e dinâmico, no qual sujeitos subalternizados se localizam. Em seguida, nos interessam as práticas de linguagem que se projetam desde o lócus enunciativo e, assim, optamos pelas 
${ }^{1} \mathrm{O}$ conceito de lugar pode apontar para diversos significados e interpretações. Assim, neste caso será considerado em referência ao encontro, à construção e manutenção de vínculos (sociais, históricos, afetivos, entre outros) que permitam que a vida de cada um de nós ganhe sentido e dignidade para ser vivida.

${ }^{2}$ Por colonialidade aqui entendemos o padrão de poder engendrado no colonialismo que consiste na implantação do sistema administrativo colonial. Esse padrão de poder não findou com o término de tal sistema e afeta diversas dimensões do ser, poder e saber; daí, portanto, a menção às diversas formas de colonialidade. Como dito antes, a decolonialidade se propõe o enfrentamento das colonialidades, por uma parte, e, por outra, uma crítica e um pensar acerca da própria configuração da lógica da

colonialidade e sua estreita relação com a modernidade. vozes de rappers do coletivo Batallones Femeninos do México, particularizando o cenário da fronteira Norte, tendo em vista sua localização geográfica e as tensões geradas na dinâmica Sul Global e Norte Global que impactam diversas dimensões da vida econômica, artística, política e cultural. Desse modo, propomos mostrar como as rappers mulheres, a partir de seu lócus de enunciação, encontram seu lugar no mundo ${ }^{1}$, por meio de um conjunto de práticas de linguagem, substancializadas na práxis de uma pedagogia decolonial.

\section{Lócus de enunciação, decolonialidade(s) e descolonização: algumas considerações}

O lócus de enunciação tem sido considerado como crucial para o entendimento acerca de que forma uma determinada racionalidade - e, na sua esteira, epistemologia - se impuseram como únicas e universais no contexto da modernidade/ colonialidade ${ }^{2}$. Remete ao questionamento de como o conhecimento que acessamos tem se espraiado, tendo em vista um determinado lugar epistêmico, cujo ponto de origem teria se estabelecido a partir da presunção de um Ego não situado, ou seja, o ponto zero do conhecimento, no qual e para o qual, não haveria relevância outros saberes e outros sujeitos e nem haveria sequer mesmo outros conhecimentos e saberes anteriores a esse. Essa discussão vem sendo aprofundada devido a algumas razões: de um lado, por problematizar o processo em que uma forma única de conhecimento se impõe sobre as demais como universal; por apontar para a instalação de uma ordem de mundo racional a partir de uma perspectiva única de conhecimento, a saber, a eurocêntrica e eurocentrada, reafirmando, consequentemente, um padrão de poder/saber (a colonialidade) com seus efeitos nas vidas de amplos coletivos humanos e por explicitar o epistemicídio e o racismo epistêmico e, de outra parte, por reivindicar um posicionamento local, no caso, afinado com o Sul Global e a partir do qual se busca empreender a crítica dos processos históricos da modernidade e de suas reverberações no padrão colonial de poder, que consiste a colonialidade e, igualmente, por ir além do provincialismo epistêmico (aqui falamos de lugar epistêmico) de homens brancos europeus ou europeizados que geraram a invisibilidade de outras experiências humanas dos 
${ }^{3}$ Por geopolítica do conhecimento, entendemos aqui as maneiras de conceber, produzir e transmitir saberes na modernidadecolonialidade elevadas à produção científica fundamentada racionalmente a uma assimilação e presunção de um conhecimento neutro e universal, a saber, eurocêntrico que acaba por expropriar e apagar outros saberes e conhecimentos, e, consequentemente, os sujeitos que os produzem. Daí, a centralidade que envolve a problemática do lócus de enunciação. subalternizados pela imposição de determinados parâmetros de gênero, sexualidade, classe e raça.

Portanto, dada a centralidadedesse tema, a problematização do lócus de enunciação tem sido de interesse do pensamento decolonial. Neste sentido, Ballestrin (2013, p. 109) menciona que diversos autores, localizados nos centros e nas periferias da produção da geopolítica do conhecimento ${ }^{3}$ (MIGNOLO, 2020; 2005), questionam o universalismo etnocêntrico, o eurocentrismo teórico, o nacionalismo metodológico, o positivismo epistemológico e o neoliberalismo científico contidos na corrente dominante das ciências sociais. Essa busca tem constituído um conjunto de elaborações denominadas Teorias e Epistemologias do Sul (SANTOS; MENESES 2010; CONNELL, 2007), que valorizam e descobrem perspectivas transmodernas, no sentido de Dussel, para a decolonização das ciências sociais. Sendo assim, o grupo da modernidade/ colonialidade se soma a um movimento mundial em andamento no sentido de refundação e descolonização epistemológica.

Nesta esteira, o lócus de enunciação, como bem assinalam alguns autores (GROSFOGUEL, 2006; 2010; BERNARDINOCOSTA; GROSFOGUEL, 2016; FIGUEIREDO; GROSFOGUEL, 2010), está associado a ideia de que o conhecimento se produz a partir de um determinado lugar geopolítico. Ora esse fato nos permite pensar em termos de uma geopolítica do conhecimento, conforme Dussel (2005) e Mignolo (2020; 2005), ou ainda, de um "corpo-política do conhecimento", conforme Grosfoguel (2010, p. 459), partindo das ideias de Anzaldúa $(1987,2016)$ e de Fanon (1967). Consequentemente, o lócus de enunciação tem a ver, segundo esses autores, com o espaço geopolítico em que os sujeitos enunciam e como nesse são apagados os lastros da localização social, política, histórica dos sujeitos bem como são desconsiderados os diversos atravessamentos de gênero, de classe, etnia, raça, por exemplo, com a instauração de um Ego não situado e universal. Assim, para Grosfoguel (2010, p. 459), a "ego-política do conhecimento" da filosofia ocidental para se manter privilegiou o mito de um 'Ego' não situado. Ora, decorrente desse fato, "o lugar epistêmico étnico-racial/ sexual/de gênero e o sujeito enunciador encontram-se, sempre desvinculados" e nesse ponto 
[...] ao quebrar a ligação entre o sujeito da enunciação e o lugar epistêmico étnico-racial/sexual/ de gênero, a filosofia e as ciências sociais conseguem gerar um mito sobre um conhecimento universal verdadeiro que encobre, isto é, que oculta não só aquele que fala como também o lugar epistêmico geopolítico e corpo-político das estruturas de poder/conhecimento colonial, a partir do qual o sujeito se pronuncia. (GROSFOGUEL, 2010, p. 459)

Em direção análoga, Figueiredo e Grosfoguel (2010, p. 228) ressaltam que essa tem sido a estratégia epistêmica para as configurações imperiais/globais ocidentais e para a hegemonia dos brancos crioulos nas Américas, pois por meio do encobrimento da localização particular do sujeito da enunciação, foram possibilitadas a expansão e a dominação coloniais europeias/euro-norte-americanas bem como o poder das elites euro-latino-americanas para edificarem uma hierarquia do conhecimento superior versus conhecimento inferior que, por sua vez, se desdobra em seres superiores versus seres inferiores no mundo. A discussão em torno desses lugares se associa com a compreensão de como esse lócus de enunciação foi sendo forjado, por meio de apagamentos e de silenciamentos epistêmicos, bem como de seus sujeitos. Dizendo em outras palavras, a quem e por qual razão esse projeto demarcou um certo lugar de enunciação e, ao fazê-lo demarcou, igualmente, quem poderia fazê-lo e como.

Contudo, ao situar o Ego, torna-se claro que nossas falas sempre se dão desde de um lugar determinado e, portanto, esse está localizado nas estruturas de poder. Sendo assim, como assinala Maldonado Torres (2019, p. 49), “o que quer que um sujeito seja, ele é constituído e sustentado pela sua localização no tempo e no espaço, sua posição na estrutura de poder e na cultura, e nos modos como se posiciona em relação à produção do saber". Lembramos que anos atrás Grosfoguel (2010, p. 459) já afirmara que não escapamos às hierarquias de classe, sexuais, de gênero, espirituais, linguísticas, geográficas e raciais do sistema-mundo patriarcal/capitalista/colonial/ moderno quando enunciamos e, igualmente, diríamos quando nos inscrevemos nessa cadeia de epistemes. Ainda neste sentido, quanto à localização geopolítica e hierarquias raciais, de classe, gênero, sexuais, salientamos que 
Afirmar o locus de enunciação significa ir na contramão dos paradigmas eurocêntricos hegemônicos que, mesmo falando de uma localização particular, assumiram-se como universais, desinteressado e não situados. O locus de enunciação não é marcado unicamente por nossa localização geopolítica dentro do sistema mundial moderno/colonial, mas é também marcado pelas hierarquias raciais, de classe, gênero, sexuais etc. que incidem sobre o corpo. (BERNARDINO-COSTA; GROSFOGUEL, 2016, p. 19)

Diante dos argumentos anteriores, acreditamos que, ao enfatizar a inter-relação entre os lugares epistêmicos e os outros saberes, ou igualmente, entre os sujeitos, conhecimentos e saberes como histórica, política e culturalmente localizados e os efeitos disso para a própria produção, validação e acesso ao conhecimento abrem-se brechas para a transformação do lugar de enunciação pela práxis humana, ou seja, por meio da ação dos sujeitos. Nesse viés, entendemos a práxis segundo Vázquez (1977), a saber, como uma prática social transformadora não limitada a um tecnicismo ou a uma pura teorização. Compartilhamos, igualmente, da ideia freiriana de práxis (FREIRE, 1979, p.15), segundo a qual reflexão e ação são indissociáveis, formando um par constitutivo, de tal sorte que não há conscientização fora da práxis, sem o ato de reflexão. Por esse motivo, consideramos a relação entre o ser e o conhecer; de

${ }^{4}$ Compreende, assim, dimensões da ordem do ser e do conhecimento (ontologia e epistemologia) bem como da ação e proposição do conhecimento no mundo social transformado (práxis).

Daí, portanto, nossa alusão a essa tripla dimensão, pensada modernamente, ou ainda, pluridimensão, na perspectiva decolonial em que se contesta, por exemplo, dicotomizações como as de teoria e prática. Aliás, tem sido central para a perspectiva decolonial o enfrentamento da lógica binária de mundo, erigida na modernidade/ colonialidade. ordem ontológico-epistêmica, mas, igualmente, praxiológica 4 . Essa assertiva sugere que tais hierarquias e hierarquizações, de certa forma, condicionam nosso espaço enunciativo e nosso espaço de enunciação, o que é bem distinto de determiná-lo.

Diante do exposto, o lócus de enunciação pode ser particular e singularmente ocupado pelo sujeito subalternizado, invisibilizado ou historicamente apagado. Dizendo de outro modo, não seria possível um lócus de enunciação sem sujeitos que nele se inscrevem e essa inscrição, no caso da racionalidade única, se estabeleceu a partir do mito do 'Ego' não situado. Torna-se preciso, então, situar o 'Ego' e que nos leva a indagar como robustecer os lugares epistêmicos com vozes insurgentes e dissonantes que se tornem fortes como uma coenunciação coletiva, política e socialmente situada. Novamente, portanto, é necessário ocuparmos os lugares epistêmicos de forma corporalizada, ou seja, de tomar corpo enquanto sujeitos. Além disso, ao mesmo tempo, em que se instaura o lócus 
de enunciação, se instauram lugares de fala e lugares de escuta; pois para que se produzam lugares de fala precisamos pressupor lugares de escuta. Quanto ao lugar de fala, Ribeiro (2019, p. 89) afirma que os sujeitos subalternizados falam a partir de suas próprias vivências, narrativas e experiências de vidas e de existência. Neste sentido, entendemos que essa fala projeta uma escuta. Essa, aliás, tem sido uma proposição nossa em construção, acorde com a perspectiva de que toda fala pressupõe uma escuta.

Considerando nossas ideias anteriores, propomos o lócus de enunciação como um espaço sócio-histórico de enunciação, apropriado pelos sujeitos e, consequentemente, instaurador de uma perspectiva outra de conhecimento dos enunciadores. $\mathrm{O}$ lócus de enunciação é onde se entrevê uma disputa interna no ato próprio de enunciar, sendo essa disputa materializada de distintas formas. Dessa maneira, ao tratar do lugar de fala, Ribeiro (2019, p. 88-89) destaca que Lélia Gonzalez, Linda Alcoff e Spivak rebatem a neutralidade epistemológica bem como reiteram o reconhecimento de outros saberes e a relevância de considerá-los localmente. Como observa Ribeiro, elas produzem discursos contra hegemônicos que desestabilizam a norma, por serem construídos a partir de outros "referenciais" e "geografias" para além das possibilidades existenciais impostas pelo regime dominante. Portanto, outros exemplos podem contribuir para que repensemos o lócus de enunciação, de maneira situada, como possibilidades de gerar uma cartografia distinta do saber/poder na qual e para a qual as práticas de linguagem, ou ainda se se prefere, os usos sociais da linguagem são cruciais, já que por meio dessas podemos situar o ego, as vozes, confrontar os lugares de fala e de escuta, inverter, subverter e combater as narrativas lineares da colonialidade.

${ }^{5}$ Por efeito de verdade, retomamos aqui a crítica a presunção da verdade como préexistente, acorde com o essencialismo. No caso, não acedemos a verdade, mas a alguns efeitos gerados que passam a ocupar a existência e a se consolidarem como verdade. Do contrário, estaríamos aderindo a tese da pré-existência da verdade.
Neste sentido, um aspecto a destacar diz respeito ao "onde se enuncia" e ao "como se enuncia". Ao estabelecer-se um lócus de enunciação inscrito em um espaço de forças espaçotemporais a partir do qual se enuncia e se é possível enunciar, é normal que ocorram tensões de diversos tipos. Como dito antes, enunciar supõe sujeitos, mas supõe igualmente que esses se defrontem com espaços privilegiados de enunciação; daí, por exemplo, podemos compreender os discursos e narrativas hegemônicos, relatos que preservam uma memória de sentidos pouco fraturada, já que produz efeito de verdade ${ }^{5}$ e totalidade 
${ }^{6}$ Deslocamos aqui a ideia de dispositivo já conhecida, mas a propomos como fundamental para a problematização do lócus de enunciação e de sua relevância para a mudança e consolidação de outras possíveis geopolíticas do conhecimento. e acabam se naturalizando e se legitimando. Um exemplo dessa lógica, é autorizar quem fala, de onde fala e como fala, por exemplo e, sendo assim, por detrás dessa autorização pensada como a força de uma autoridade moral, social ou ainda institucional - está claramente definida uma ordem para as práticas de linguagem, que acaba por definir uma lógica de produção de quais são as práticas de linguagem que podem ser perpetuadas e consagradas. Neste sentido, o lócus de enunciação se torna decisivo para problematizar quem fala e por qual razão fala; de onde fala; como sua fala é silenciada ou escutada; como sua fala se potencializa ou não.

Acreditamos que essa dimensão nos ajuda a entrever como o espaço das falas dos sujeitos é marcado por essas contradições e incoerências, mas não como algo negativo ou que deva ser superado ou suplantado, já que indicia como os processos de compreensão e de criação de inteligibilidades outras passam, de forma inevitável, por atravessamentos de posições, por disputas de sentido e, enfim, por deslocamentos dos sujeitos em posicionamentos dinâmicos. Nesse espaço se situam os sujeitos em suas falas e, por isso, instauram nele lugares ou espaços enunciativos concretos. Para que esses espaços se materializem precisam ser ocupados e, com tal fim, é preciso sujeitos que, por sua vez, como dissemos, nem sempre ocupam linearmente posições epistêmicas comuns. Assim, interessa destacar como essas zonas de enunciação são vaso comunicantes, ou seja, não refletem de forma binária ou dicotômica ou polarizada como se a fala de sujeitos se aderisse a um lugar epistêmico único.

Tendo em vista essa problemática, vemos no lócus de enunciação um dispositivo ${ }^{6}$, através do qual os sujeitos podem ocupar determinados lugares de fala e se tornarem enunciadores ao se inscreverem nesse espaço trazendo para ele sua corporalidade, suas narrativas, suas formas de ser, pensar e sentir, suas subjetividades. Neste sentido, concordamos com Bernardino-Costa e Grosfoguel (2016, p. 21) em que "central ao projeto político-acadêmico da decolonialidade é o reconhecimento de múltiplas e heterogêneas diferenças coloniais, assim como as múltiplas e heterogêneas reações das populações e dos sujeitos subalternizados à colonialidade do poder". A ideia, portanto, é que o lócus de enunciação é crucial enquanto um dispositivo que permite aos sujeitos 
subalternizados historicamente provocar e incitar outras formas de saber, de dizer, de ser, de existir que se materializam na práxis e nas pedagogias decoloniais (WALSH, 2013; MOTA NETO; STRECK, 2019). Assim sendo, no tocante às diversas coletividades que ocupam o Sul Global, aqui entendido como uma metáfora do sofrimento humano, proposta por Santos (2010), o lócus de enunciação é apropriado pelos sujeitos, enunciadores do Sul Global, que o fazem como forma de dar mais visibilidade não somente as suas próprias práticas de existências bem como as de linguagem que nele acontecem e se produzem.

Portanto, o lócus de enunciação, enquanto dispositivo epistêmico-ontológico-praxiológico, corporifica um espaço de enunciação situado historicamente no Sul Global; um espaço ocupado por sujeitos subalternizados para concretização de ações e práticas de resistência, ou mais amplamente, de práticas de insurgência e de decolonialidade. Nessa mesma ordem de ideias, o lócus de enunciação é central para propor um contradiscurso, ou ainda, práticas contrárias à ordem hegemônica e, além disso, por explicitar como os sujeitos desenham uma cartografia-outra em que demandam a inversão do lugar de fala (RIBEIRO, 2019) legitimando esse lugar de forma corporificada, demarcando os atravessamentos de classe, gênero, sexualidade, etnia, raça.

Como vimos nos preocupou detalhar antes em que consiste nosso entendimento acerca do lócus de enunciação e por qual motivo esse pode ser considerado como um dispositivo por meio do qual os sujeitos materializam práticas e ações que convergem para a materialização de uma práxis decolonial. Tendo em conta tal compreensão, discorremos a seguir sobre as práticas de linguagem que se projetam a partir de um lócus determinado e, para tanto, optamos pelas vozes de rappers mulheres do Coletivo Batallones Femeninos do México, realçando o cenário da fronteira Norte - por sua localização geográfica e pelo espaço de tensões gerados na dinâmica Sul Global e Norte Global em diversas dimensões da vida econômica, artística, política e cultural. 


\section{Coletivo Batallones Femeninos: cartografando uma pedagogia decolonial no Norte-Sul}

Ao longo desta seção, nosso propósito consiste em destacar como as rappers mulheres, desde de seu lócus de enunciação, encontram seu lugar no mundo, por meio de conjunto de práticas de linguagem que sob a forma de práxis decoloniais, conformam uma pedagogia-outra. Mencionamos pedagogiaoutra e não uma outra pedagogia por não se tratar de mais uma entre as já existentes. De acordo com Walsh (2013, p. 29), a pedagogia e o pedagógico não são pensados aqui de forma instrumentalista de ensino e transmissão do saber e nem estão limitadas ao campo da educação ou espaços escolarizados. De tal modo, coincidimos com a autora em que as lutas sociais são cenários pedagógicos nos quais os participantes colocam em prática suas pedagogias de aprendizagem, desaprendizagem, reaprendizagem, reflexão e ação. Instaura-se, no nosso modo de ver, um processo de desautomatização do aprendido e apreendido, que sob outra perspectiva passa a ser percebido e desaprendido, reaprendido e se torna uma experiência outra para os sujeitos. Consoante essa proposição, as ações orientadas no sentido de mudar a ordem do poder colonial partem frequentemente da identificação e do reconhecimento de um problema, anunciando seu inconformismo e oposição

${ }^{7}$ Depreendemos da citação anterior, que a pedagogia decolonial se constitui de práxis decoloniais, entendidas como esse conjunto de teorias-práticas mobilizado pelos sujeitos. Neste sentido, sugerimos que esse conjunto aponta para uma pluralidade e diversidade de práxis, que se atualizam e se concretizam nos diversos territórios. Por isso, são marcadas em sua pluralidade; aliás, esse ponto reforça a oposição entre saberes e conhecimentos universais versus saberes e conhecimentos pluriversais. Em outras palavras, entre paradigmas que englobam a racionalidade única e os que envolvem a pluriversalidade. à condição de dominação e opressão, organizando-se para intervir e tornar possível outra situação que não a atual. Dessa forma, por meio de práticas políticas, epistêmicas, vivenciais e existenciais se luta pela transformação da colonialidade e dos princípios sobre os quais o conhecimento, a humanidade e a existência foram circunscritos, controlados e subjugados. Segundo a autora, as pedagogias são práticas, estratégias e metodologias que se entretecem e se constroem seja na resistência, seja na oposição, como insurgência, afirmação, resistência e reumanização. Na mesma direção, a pedagogia decolonial $^{7}$ constitui

[...] o conjunto de teorias-práticas de formação humana que capacitam os grupos subalternos para a luta contra a lógica opressiva da modernidade/colonialidade, tendo como horizonte a formação de um ser humano e de uma sociedade livre, amorosa, justa e solidária. Essa pedagogia deve ser entendida no contexto das lutas decoloniais, que pretendem a viabilização da humanidade contra a matriz colonial e 
seu padrão de racialização-desumanização que há mais de 500 anos vêm oprimindo e vitimando homens e mulheres (WALSH, 2013). (MOTA NETO; STRECK, 2019, p. 209)

Maldonado Torres (2013, p. 12), por sua vez, menciona que as pedagogias decoloniais fazem parte do discurso da colonialidade e da decolonialidade do ser conectado com o fazer, com práticas de desaprender e reaprender tanto em nível teórico, como artístico e de ação política. De modo similar, Walsh (2013, p. 19) propõe que as pedagogias decoloniais podem ser consideradas como "as metodologias produzidas nos contextos de luta, marginalização, resistência", ou ainda, como práticas insurgentes que racham a modernidade/ colonialidade e tornam possível maneiras outras de ser, estar, pensar, saber, sentir, existir e viver com. As pedagogias decoloniais se desenham a partir de diferentes lugares de atuação e enunciação; encaminhadas no sentido de propor formas de ação (metodologias), práticas e estratégias que desestabilizam a ordem dominante e apontam possibilidades outras. Compartilhamos desse mesmo entendimento a respeito das pedagogias decoloniais e, desse modo, nos interessa focalizar, de modo particular, o Coletivo Batallones Femeninos, dada sua relevância e aderência a atitudes e práticas que fazem parte do cenário das pedagogias decoloniais, tendo como espaço a fronteira Norte do México, em que se desenrolam ações e práticas que configuram uma práxis que se conecta um fazer pedagógico decolonial.

Sendo assim, inicialmente, discorremos sobre a fronteira Norte para que possamos ter em conta como em nela situamos essas práticas e, em especial, as do Coletivo Batallones Femeninos. Em seguida, passamos para alguns exemplos de como essa pedagogia decolonial se delineia, tendo em vista a seleção de algumas materialidades discursivas produzidas e difundidas pelo Coletivo que nos permitam visibilizar o que estamos discutindo aqui.

Tratando das fronteiras do México, García Amaral (2008, p. 42) menciona que esse país possui duas, quais sejam, a fronteira Norte e a Sul. A do Norte se limita com o "país mais poderoso do planeta" e mede $3.152 \mathrm{~km}$, enquanto a segunda, a do Sul, com a Guatemala e Belize, tem a dimensão de 1.149 $\mathrm{km}$. A fronteira Norte abriga seis dos trinta e um estados do 
México, de oeste a leste: Baixa Califórnia, Sonora, Chihuahua, Coahuila, Novo León e Tamaulipas. Já no lado estadunidense se situam quatro estados: Califórnia, Arizona, Novo México e Texas. Já de modo particular quanto à fronteira Norte, Guillén López (2007, p. 9-11) assinala que essa se constitui como uma região de crescente relevância no panorama nacional, dadas suas características demográficas, sociais, econômicas e geopolíticas. A complexidade da sociedade fronteiriça é acompanhada de fortes contrastes em comparação com o país vizinho, além dos internos e dos existentes entre esses processos. Encontram-se, assim, empresas com um elevado nível de tecnologia de qualidade mundial, ao lado de espaços urbanos carentes de equipamento mínimo e com amplos setores sociais vivendo em áreas sem serviços públicos e em precárias vivendas. Já Ojeda de la Peña (2013, p. 649) menciona o fato de haver diversas formas de definir a fronteira Norte. Uma das definições operativas se baseia no nível de desagregação geográfica-administrativa e neste sentido as entidades federativas e os munícipios costumam ser empregados com frequência. Nesta direção, de forma geral, se mencionam cinco estados nortenhos que fazem fronteira com Estados Unidos: Baixa Califórnia, Sonora, Chihuahua, Coahuila e Tamaulipas, e, mais recentemente, a inclusão de Nueva León. Consideramse trinta e oito municípios fronteiriços que limitam com os Estados Unidos. Outra definição se fundamenta no conjunto das principais cidades ou municípios fronteiriços que possuem uma contraparte urbana do lado estadunidense, a saber, Tijuana, Mexicali, Nogales, Ciudad Juárez, Piedras Negras, Nuevo Laredo, Reynosa e Nogales. A fronteira é considerada urbana e nessas oito localidades reúnem a maior parte da população fronteiriça, sendo que a concentração da população no censo de 2000 apontava que Tijuana e Ciudad Juárez representavam $44.5 \%$ dos residentes fronteiriços.

Zúñiga González (2011, p. 288), a partir de Miranda, menciona a relevância da vizinhança com o país do Norte e assinala que a fronteira não é somente uma definição do espaço territorial, ou mesmo, somente uma região de conflitos e tensões internacionais, mas também uma região geográfica na qual se desenham linhas divisórias que separam realidades diferentes. Zúñiga González (2011, p. 287-295) problematiza que as relações entre Norte e Sul, ou seja, entre um país do 
Norte (Estados Unidos) e outro do Sul (México) não produz os mesmos efeitos que podemos observar em outras partes do mundo e que o ponto de proximidade, seguramente o mais atraente porque é o menos comum, se apresenta como o arquétipo e o testemunho da fronteira México-Estados Unidos. Para esse autor, se trata de um arquétipo porque representa o que acontece em toda a fronteira e testemunho porque o que ali acontece anuncia o que passará no resto das cidades fronteiriças.

Ressaltamos que, de forma paradoxal, a fronteira Norte, assim denominada, é um Sul, tal como temos pensado, pois faz parte de uma cartografia, marcada por uma indelével separação entre o Sul Global e o Norte Global, na forma do que Santos (2007) denominou como sendo "linhas abissais". Nesta direção, as linhas abissais remetem às desigualdades e assimetrias culturais, sociais e de saberes referentes ao sistema mundial, visto que "deste lado da linha" concentra-se o pensamento hegemônico moderno ocidental, modelado pela civilização europeia (eurocentrista), firmado na imagem do homem branco, cristão e heterossexual, e, "do outro lado", os "marginalizados", "desqualificados", de um mundo subalterno em que seus conhecimentos (saberes) são desconsiderados/ inexistentes/anulados/invisibilizados pelos que estão "deste lado da linha". Para Santos (2019), o Sul aqui anti-imperial, o Sul das epistemologias do Sul, não como uma imagem invertida do Norte das epistemologias do Norte. Portanto, nessa ordem de ideias

[...] o Sul que se opõe ao Norte não é o Sul constituído pelo norte como vítima, e sim o sul que se revolta a fim de ultrapassar o dualismo normativo vigente. A questão não consiste em apagar as diferenças entre norte e sul, e sim apagar as hierarquias de poder que os habitam. As epistemologias do Sul afirmam e valorizam assim as diferenças que permanecem depois da eliminação das hierarquias de poder. (SANTOS, 2019, p. 26)

Em nossa contextualização da fronteira Norte, chamamos a atenção quanto à heterogeneidade e complexidade desse espaço devido as diferenças ecológicas, sociais, demográficas e econômicas entre as sub-regiões. Ademais, sinalizamos para a aproximação da ideia da divisão de mundos marcada, 
${ }^{8}$ As expressões

"femicídio" ou

"feminicídio" são empregadas para denominar mortes violentas de mulheres em razão do gênero, por sua "condição" de mulher. O conceito de "femicídio" foi empregado pela primeira vez na década de 1970, contudo nos anos 2000 seu emprego se difundiu no continente latino-americano por causa das mortes de mulheres ocorridas no México, país em que o conceito ganhou nova formulação e novas características por meio da designação de "feminicídio" (ONU MULHERES, 2016, p. 20). Consoante esse entendimento, aqui empregamos feminicídio. a partir dessa cartografia, entre o Sul Global e o Norte Global. Dito isso, passamos a seguir a alguns exemplos de como essa pedagogia decolonial se concretiza, tendo em vista a seleção de algumas materialidades discursivas, do Coletivo Batallones Femeninos. Nosso propósito consiste em ressaltar a multiplicidade de práticas que emergem e se entretecem como parte da pedagogia decolonial e, na esteira desse movimento, o de reiterar a necessidade de uma escuta dessas vozes, cujas ressonâncias se fazem sentir para além dos espaços-territórios em que se produzem.

Lembramos que as rappers femininas se contrapõem a uma cultura fortemente dominada por homens, como a do hip-hop. Conforme Díez Salvaterra (2016, p. 46), a irrupção de rappers mulheres no mundo global questiona a produção e manutenção de uma subjetividade da mulher gerada partir de uma matriz branca, eurocêntrica, heterossexista e burguesa. Portanto, incorpora a luta pela igualdade, e, ao mesmo tempo, reivindica as diferenças, tendo em conta a inferiorização racial e a subordinação de gênero atreladas ao padrão colonial de poder, à colonialidade. Neste viés, não só as relações de gênero, mas também as étnicas, raciais e de classe, são confrontadas em suas múltiplas dimensões.

No caso do Coletivo Batallones Femeninos, desde um território complexo, tal como o da fronteira Norte, de forma mais ampla, e, particular, o da Ciudad Juárez, jovens mulheres se apropriam do hip-hop e promovem práticas e atitudes que apontam para a constituição de uma pedagogia da resistência e da luta, consoante nosso entendimento da pedagogia decolonial. Conforme Alcocer Perulero (2020, p. 170), Ciudad Juárez foi considerado o caso mais emblemático e notório relacionado à violência de gênero ${ }^{8}$. Ainda que não tenha sido o único espaço em que se apresentou tal problema, foi pioneiro em protesto social tanto no México como em outras partes do mundo. Gerou-se, assim, a "Rede Transnacional dos Direitos das Mulheres de Ciudad Juárez" que pressionou o governo mexicano a agir e a enfrentá-la. A cidade assumiu esse protagonismo, sendo relevante para tanto as ações não governamentais e, em especial, os movimentos locais gerados que não somente alertam sobre a situação local, mas também geram efeitos em nível nacional e internacional. 
Avançando em nossas considerações, é importante situar o Coletivo Batallones Femeninos no cenário de pluralidade do feminismo latino-americano, particularmente, o mexicano. Neste sentido, lembramos que a organização e mobilização de mulheres na América Latina não é algo recente, visto que há uma trajetória e uma história que precisam ser consideradas para a compreensão da importância das práticas e ações de coletivos tal como no caso o Coletivo Batallones Femeninos. Neste viés, Quiroz Pérez (2017) contextualiza o feminismo desde uma perspectiva histórica, destacando os grupos menos visibilizados tais como o das mulheres indígenas e dos coletivos de criação recente, tal é o caso dos agrupamentos juvenis. A autora afirma que não se trata de abstrair as contribuições do passado, mas, ao contrário, situar as formas de expressão femininas mais atuais ou alternativas em um movimento amplo, cujas histórias e problemáticas diversas variam conforme o contexto em que ocorrem ou se desenrolam. Por isso, é preciso reconhecer a diversidade dos movimentos de mulheres que, de modo geral, são englobados em um bloco monolítico e rotulados de "feminismos latino-americanos".

Situando-se entre essas vertentes menos visibilizadas do movimento, os coletivos mexicanos promovem um pensamento fronteiriço e o empoderamento em suas práticas, como assinala a mesma autora. Opondo-se a situação de vítimas passivas, Quiroz Pérez (2017, online) recorda que alguns desses coletivos, tais como, por exemplo, Kolectiva Fronteriza e Mujeres Trabajando nasceram no contexto particular de violência sistemática contra as mulheres, no caso, a fronteira entre México e Estados Unidos; um dos lugares em que essa violência se manifesta de forma impactante, haja vista que, como dito, Ciudad Juárez se converteu em um lugar tristemente conhecido pelo alto número de feminicídios.

Ainda de acordo com Quiroz Pérez (2017, online), o Kolectiva Fronteriza se formou em 2009 e nesse momento propôs visibilizar e empoderar as mulheres que trabalhavam arduamente em suas casas ou em outros setores econômicos e que tinham perdido a seus familiares. O grupo expandiu-se e um dos subgrupos passou a constituir o do Batallones Femeninos, formado por cantoras de rap que reúne atualmente catorze mulheres originárias de várias partes, como Ciudad de México, Querétaro, Tepic, Ciudad Juárez, Seattle e Chicago. O Coletivo 
Batallones Femeninos articula música hip-hop e ativismo, desenho, arte urbana e educação. Participam desse Coletivo: Obeja Negra; Lady Liz; Kiara; Murder; Bawa; Blanca; Dilema; Candy; Andrita Marte; Xirena; Jelout; Sam e Dun Dun Seven e Murder e Dilema. Batallones Femeninos, conforme Quiroz Pérez (2017), mostram uma consciência política importante, produto do diagnóstico de sua posição de mulheres e embora nem todas se autodefinam como feministas, nem possuam uma base teórica feminista, é o coletivo cujo discurso feminista é mais acentuado, não de maneira teorizada, mas experienciada; daí, portanto, sua relevância e nosso interesse. Nesta direção, Quiroz Pérez (2017), tratando dos coletivos juvenis femininos e sua inserção nos feminismos latino-americanos, observa que esses evidenciam os limites e omissões do movimento anterior que, em dado momento se considerou universal e, assim, as mais jovens se distanciam da teoria a qual acessam de maneira indireta, através de oficinas, vídeos, canções, post ou tweets. Outro ponto a destacar diz respeito a proposta de reatualizar o modo de ação e neste sentido um dos mais notáveis é o emprego do vídeo e das redes sociais para amplificar as mobilizações. Por isso, os movimentos estão ancorados em contextos históricos e sociais precisos, ou seja, são localizados, mas, ao mesmo tempo, se conectam com outros e se amplificam. Tal é o caso da influência da cultura hip-hop no México ou a preocupação por temas tais como o aborto ou as esterilizações forçadas no Peru.

Passamos, a seguir, a alguns materiais produzidos e

${ }^{9}$ Optamos pelo Facebook pelo acesso à rede $\mathrm{e}$ as imagens e vídeos disponibilizados publicamente. disponibilizados pelo Coletivo Batallones Femeninos, a partir de sua rede social, o Facebook ${ }^{9}$ e outros no Youtube. Em tal recorte buscamos visibilizar algumas práticas, que enfatizassem movimentos do Coletivo no sentido de enfrentamento das situações de violência contra a mulher e feminicídio. Por isso, nessa seleção reunimos uma mostra com o intuito de ilustrar como as práticas e ações do coletivo se projetam enquanto uma práxis decolonial, de forma a destacar o que consiste, no nosso modo de ver, uma pedagogia-outra. Considerando a visibilidade de tais práticas, apresentamos a seguir alguns exemplos, tendo presentes a relevância desse material como parte de uma práxis decolonial e o conjunto desses materiais como parte desse movimento decolonial empreendido pelo Coletivo. O material está organizado da seguinte forma: 
${ }^{10}$ Tradução livre nossa:

"Nenhuma mais".
${ }^{11}$ Tradução livre nossa: "Nos queremos vivas". grupo 1 (materiais digitais de divulgação do Coletivo); grupo 2 (vídeos: transmissões ao vivo e transmissões em geral) e grupo 3 (vídeos: apresentações). Passamos, então, a nossos materiais.

Quanto ao grupo 1 (materiais digitais de divulgação do Coletivo), compreende dois materiais, conforme seguinte quadro (Quadro 1).

Quadro 1 - Sumário dos materiais produzidos e disponibilizados pelo Coletivo

\begin{tabular}{|l|l|}
\hline \multicolumn{2}{|c|}{ Grupo 1: materiais digitais de divulgação do Coletivo } \\
\hline Tipo de dados/ Imagens & \multicolumn{1}{c|}{ Descrição } \\
\hline & $\begin{array}{l}\text { Material disponibilizado na } \\
\text { rede social, com destaque para o } \\
\text { enunciado "Ni una más"10. }\end{array}$ \\
\hline
\end{tabular}

Fonte: elaboração própria.

Quanto aos primeiros materiais destacados do grupo 1 (imagens 1 e 2), chama nossa atenção como o Coletivo se firma enquanto tal, ou seja, como transparece uma construção identitária do grupo e como se reforça uma práxis de resistência associada à luta feminina pela sua existência, já que o que está em tela é o feminicídio. Neste sentido, se flagram nessas imagens um posicionamento do Coletivo quanto à sua luta $\mathrm{e}$ quanto à sua própria existência. A escolha de ícones como a 
Catrina, acompanhada da cruz, ou ainda, a imagem da jovem com camiseta de cor rosa envolta em uma aura dourada, remete ao universo religioso - associado à Virgem - servindo de moldura para a jovem de bandana e luvas de lutadora. O signo religioso, especialmente a cruz como símbolo do Cristianismo, passa a um pano de fundo no qual se inscreve a imagem da mulher, disposta a lutar contra a violência de gênero, o que aponta para uma perspectiva-outra do lugar dessa mulher em uma sociedade identificada com determinados valores religiosos, no caso, a religião cristã. Porém, a cruz é também associada à morte e, no caso a de mulheres, trazendo a inscrição "Ni una más", que subverte àquela inscrita na cruz INRI (Iesus Nazarenus Rex Iudaeorum).

Observando ambas as imagens, o Coletivo materializa sua forma de luta apropriando-se e transformando ícones, ancorados em uma certa tradição de mundo e valores ocidentais, de cunho cristão, mas ao fazê-lo reveste de suas experiências e suas referências de mundo, deslocando-as por meio atitudes decoloniais e por meio de suas narrativas de luta e resistência. $\mathrm{O}$ conjunto dessas imagens pode levar a uma constituição identitária do Coletivo e de suas ações e práticas, em que no primeiro plano, se destaca como as mulheres visibilizam suas práticas de enfrentamento valendo-se de um espaço de enunciação tal como o da rede social. Esse conjunto de imagens aponta para um fazer decolonial, como parte de uma pedagogia decolonial de resistência e de enfrentamento; contudo, advertimos que estamos pensando em um conjunto de práticas e ações que, na sua heterogeneidade, convergem para a materialização de uma pedagogia decolonial. Assim, passamos a seguir para o seguinte grupo.

Quanto ao grupo 2 (transmissões ao vivo e transmissões em geral), compreende três vídeos, conforme o seguinte quadro (Quadro 2). 
${ }^{12}$ Tradução livre nossa: "Mañanitas (tipo de composição musical) para Esmeralda Castillo Rincón desaparecida em Ciudad Juárez faz já 14 anos".

\footnotetext{
${ }^{13}$ Tradução livre nossa: "Leitura de manifesto e formulário de solicitação de demanda por justiça no caso do feminicídio de Isabel".
}

\author{
${ }^{14}$ Tradução livre \\ nossa: "Oficina de \\ RAP "Degeneradas" \\ no ENES dentro do \\ Festival hip-hop e \\ Gênero na UNAM \\ campus Morelia \\ Michoacán". \\ ${ }^{15}$ Tradução livre \\ nossa: “Desperta, \\ meu bem, desperta/ \\ Veja, já amanheceu/ \\ Os passarinhos cantam \\ já/A lua já despontou".
}

${ }^{16}$ Silva Lodoño (2017, p. 147-174) discute os sentidos derivados de ser mulher jovem na Ciudad de Juárez, por meio da análise dos processos subjetivos mediante os quais mulheres jovens que produzem hip-hop, de modo especial o rap, questionam, subvertem e/ou reproduzem as representações de gênero. Para tanto, se volta para o significado de identificar-se como "as vivas de Juárez", menção aqui empregada por nós.
Quadro 2 - Sumário dos materiais produzidos e disponibilizados pelo Coletivo

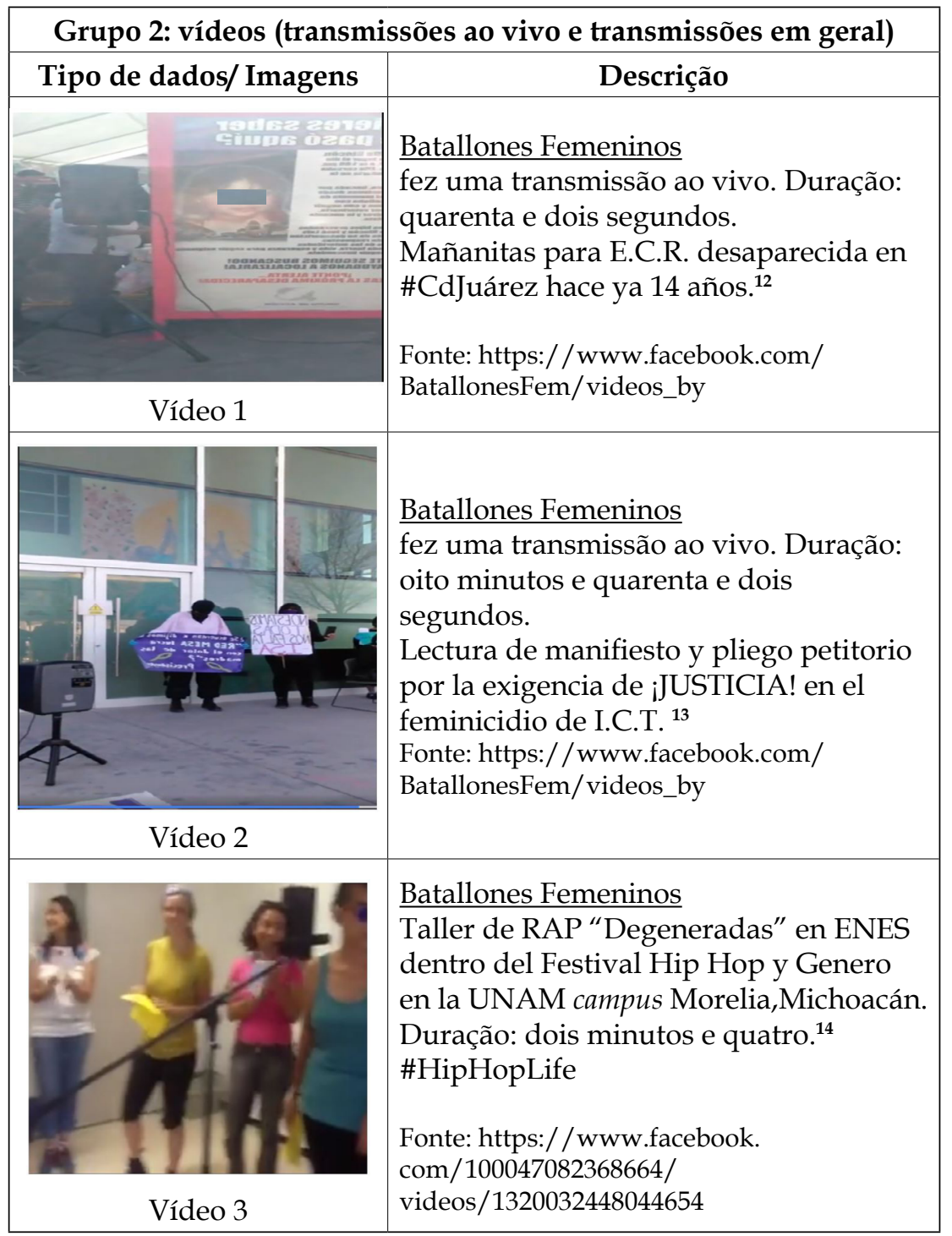

Fonte: elaboração própria.

O vídeo 1 é uma transmissão ao vivo, de 42 segundos, em que se mostra um cartaz de E.C.R., de Juárez, desaparecida desde 2009 aos quatorze anos, após a entoação de uma canção, a Mañanita, com os versos "Despierta, mi bien, despierta/Mira que ya amaneció/Ya los pajaritos cantan/La luna ya se metio" ${ }^{\prime 15}$. A escolha desse material se deve a memória das "mortas de Juárez" que se contrapõe às "vivas de Juárez"16, movimento que reivindica a existência e se reforça na canção tradicional entoada, 
17Outras informações sobre o caso se podem acessar nas mídias, pois há ampla divulgação do caso.

${ }^{18}$ Esse ocorrido gerou protestos de mulheres pela justiça e contrários à violência machista, nutridos pelo descontentamento social e organizados por coletivos feministas, antes da chegada da pandemia, conforme López (2021).

\footnotetext{
${ }^{19}$ Em espanhol se emprega delito e crime como equivalentes; contudo, delito predomina no campo do Direito e crime no da Sociologia. No caso, o órgão tem por finalidade investigar e tratar dos delitos relacionados com a violência contra mulheres e meninas (FISCALÍA GENERAL DEL GOBIERNO DE CHIHUAHUA, online).

${ }^{20}$ Tradução livre nossa: “Ministério Público Especializado no atendimento às mulheres vítimas de crime por motivos gêneros".
}

associada a festas de aniversário, celebrações e batizados. A transmissão se soma a de outras reações disponíveis em redes sociais de grupos feministas, usuárias de Twitter e Facebook ${ }^{17}$, a qual se junta o Coletivo. Desse modo, estamos diante de um conjunto de práticas e ações que, coletivamente, aponta para uma pedagogia-outra, por meio da qual se reivindica o não esquecimento da jovem desaparecida, como forma de não esquecimento de nenhuma, ou seja, reforçando-se o sentimento de pertencimento. Quanto ao vídeo 2, a transmissão feita é a da leitura de um manifesto elaborado coletivamente e de um formulário de petição de justiça a ser entregue aos escritórios de defesa da mulher. A leitura se inicia com a menção à data de 18 de janeiro de 2021, dirigindo-se ao "Estado feminicista", o Coletivo se manifesta a respeito do primeiro ano do homicídio de I.C.T. ${ }^{18}$ bem como dos mais de 2300 homicídios de mulheres, considerando-se tanto Ciudad Juárez como o restante do país. No manifesto, é exigida justiça para o caso de Isabel, "companheira e irmã" bem como pelas demais mulheres; se alude ao Estado ausente, à torpeza, negligência e misoginia e, igualmente, ao poder patriarcal. Chama a atenção, o apelo dirigido as mulheres de que o mais urgente são as suas vidas e a chamada para que se organizem em seus bairros, escolas, trabalho, com seus familiares e amigos, no sentido de criarem uma rede solidária para cuidar umas das outras e a si mesmas, o que, aliás, se traduz na forma da sororidade. Neste sentido, se delineia uma pedagogia do cuidado, que, no caso, implica uma forma de enfrentamento da violência e, ao mesmo tempo, um cuidar coletivo que reafirma a importância de ações não governamentais, mas que, ao mesmo tempo, reivindica que o Estado assuma suas responsabilidades no que diz respeito aos casos de feminicídios e homicídios que vitimizam as mulheres. Já quanto ao formulário de petição, esse é dirigido à "Fiscalía Especializada en atención a las mujeres víctimas de delito ${ }^{19}$ por razones de género"20 (preservamos a forma em espanhol), da Zona Norte, encaminhado pela Organização Ampla de Mulheres de Ciudad Juárez e por coletivos, entre os quais se incluem Batallones Femeninos. Em tal documento se demanda por justiça e, igualmente, se encaminham algumas ações no tocante à resolução dos casos de homicídios e feminicídios. Neste sentido, o Coletivo igualmente tem uma aderência a esse movimento, compartilhando em sua rede social a 
${ }^{21}$ Tradução livre nossa: "Tomada da palavra".

\footnotetext{
${ }^{22}$ Tradução livre nossa: “Todxs juntxs contra violência de gênero! Parem os feminicídios!".

${ }^{23}$ Tradução livre nossa: "Nunca mais um México sem nós".

${ }^{24}$ Tradução livre nossa: “Um mundo onde caibam muitos mundos".
}

transmissão da leitura desses textos. Essas transmissões demarcam, no espaço social da mídia, um posicionamento do Coletivo quanto ao feminicídio e à violência imposta as mulheres, mas igualmente acentuam a reinvindicação de uma ação do estado no sentido de propor vias de enfrentamento e o clamor por justiça. Neste viés, vemos um movimento de coenunciação aqui, pois o Coletivo compartilha esses vídeos em suas mídias, juntamente com outros movimentos e outros coletivos. Já o vídeo 3 foca em uma oficina de rap no Festival hiphop e gênero da UNAM (Universidade Autônoma do México), campus de Morelia, Michoacán. Selecionamos esse material para realçar como o Coletivo difunde atividades realizadas que envolvem o rap e como essas se aproximam do universo das mulheres, reafirmando, consequentemente, o espaço desssas no rap. Portanto, o Coletivo contribui para reforçar como o rap promove outras aprendizagens para as mulheres e se soma a sua luta contra a violência e o feminicídio. No Facebook há outros vídeos similares bem como cartazes de oficinas de rap, o que mostra ser essa uma das práticas recorrentes realizadas tanto por outras rappers como pelo Coletivo. A importância dessas oficinas se associa, igualmente, com a da proposição da "toma de la palabra"21 pelas mulheres como forma de resistência, reinvindicação e insurgência, ponto que retomamos logo mais.

Quanto ao grupo 3: vídeos (apresentações), compreende três vídeos (vídeo 4, 5 e 6), conforme Quadro 3, na página seguinte.

O vídeo 4 é o da apresentação de Otro mundo es posible. Destacamos a menção a Marichuy Patricio (María de Jesus Patricio Martínez), liderança indígena, escolhida pelo Congresso nacional Indígena para representar os povos indígenas e o movimento zapatista nas eleições presidenciais do México no ano de 2018. Sobressaem, igualmente, o posicionamento contrário ao sistema capitalista, patriarcal e racista bem como as faixas com imagens de Emiliano Zapata, o cartaz na cor lilás com os dizeres " $i$ Todxs jutxs contra la violencia de género! ;Alto a los femicidios! 22"; a imagem de um mural onde se lê: "Nunca más un México sin nosotras ${ }^{23 "}$ e a imagem de um muro com a inscrição: "Un mundo donde quepan muchos mundos"24. Esses exemplos acentuam o posicionamento do Coletivo com relação à política atual, reafirmando-se contrárias ao projeto de mundo que se impõe. Nesta direção, por meio de outros textos, ressignificados pela experiência do Coletivo, são confrontadas as colonialidades e confirmada a ideia de um mundo diverso e plural. 
25 Tradução livre nossa: "Outro mundo possível".
${ }^{26}$ Tradução livre nossa: "Livre, Linda e LoucaBatallones Femeninos Nos queremos vivas".

${ }^{27}$ Tradução livre nossa: 'Tomar a palavra".
Quadro 3 - Sumário dos materiais produzidos e disponibilizados pelo Coletivo

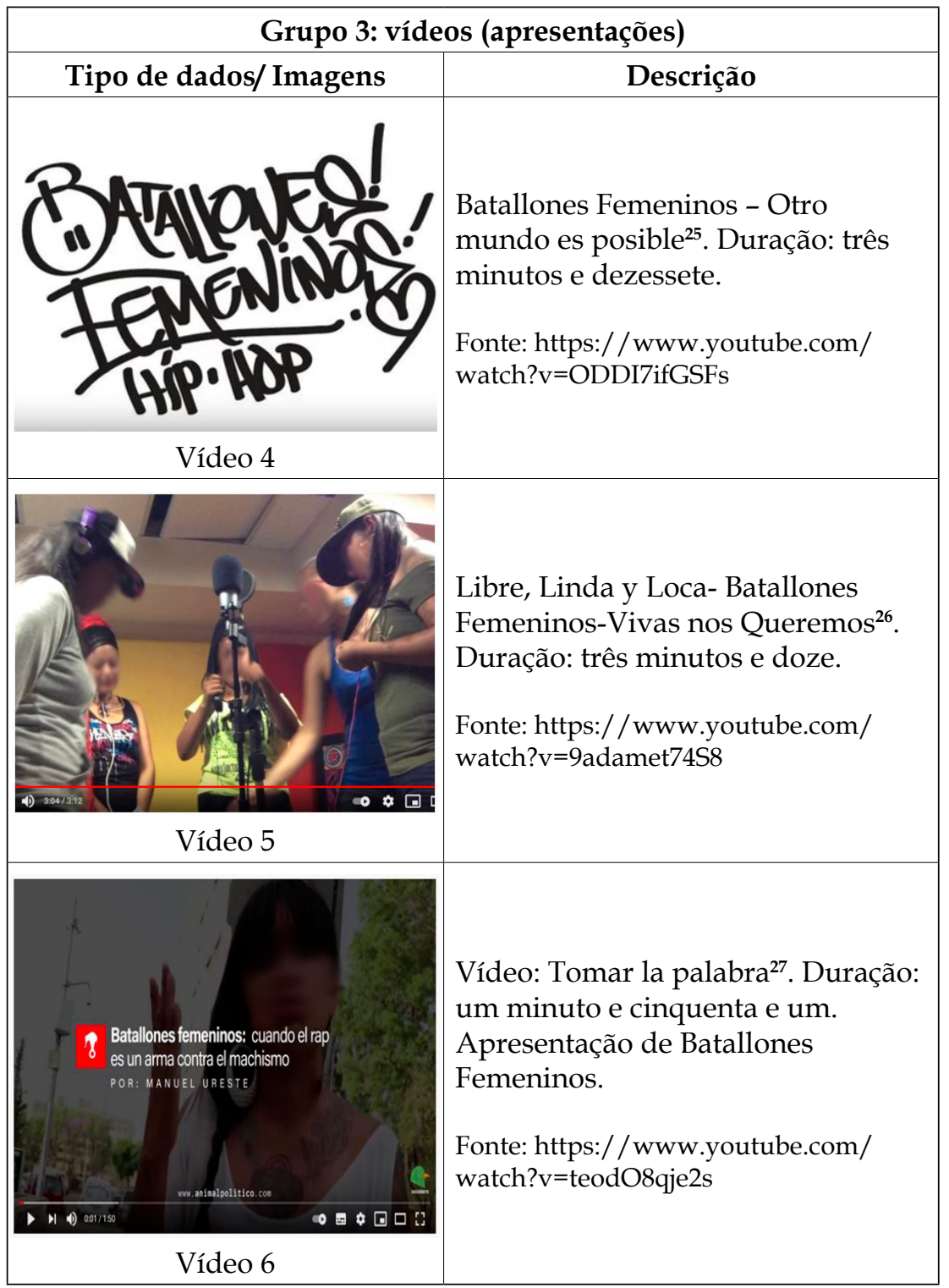

Fonte: elaboração própria.

Já o vídeo 5, intitulado "Vivas nos queremos", faz parte de um movimento de enfrentamento à violência de gênero. O lema "Vivas nos queremos" tornou-se popular a partir da mobilização contra as violências machistas denominadas \#24, a mesma que se realizou em mais de quarenta cidades mexicanas no dia 24 de abril de 2016 (MEYRA, 2016, online). A relevância desse movimento consiste em situar as mulheres nos seus diferentes 
${ }^{28}$ Tradução livre nossa: [...] contra o machismo, violência, patriarcado e exploração, morte, feminicídio, abandono.

${ }^{29}$ Tradução livre nossa: [...] pela equidade, proteção, liberdade, sororidade.

${ }^{30}$ Tradução livre nossa: uma coletiva de mulheres.

${ }^{31}$ Tradução livre nossa: combatemos todas as violências contra nossas corpas. territórios, com ênfase na concepção de mulheres concretas que lutam e enfrentam as distintas formas de opressão, dominação e violência engendradas pelo racismo, colonialismo, patriarcado e capitalismo. Ademais, explicitam a capacidade de organização das mulheres de maneira coletiva e que se identificam através das formas de opressão compartilhadas. Assim, ao incorporar esse lema, o Coletivo não somente se alinha a esse movimento maior como também o faz localmente bem como coloca em prática a sororidade. Neste sentido, destacamos que a retomada de "Vivas nos queremos" na letra, diante de um posicionamento "contra el machismo, violencia, patriarcado y explotación, muerte, feminicidio, abandono ${ }^{28 "}$ " se contrapõe ao da "por la equidad, protección, libertad, sororidade $e^{29 \prime}$, demarcando para tal a co presença do lema evocado e ressignificado, cuja ressonância se atualiza em outros espaços e por meio de diversas tomadas da palavra. Quanto ao vídeo 6, intitulado Tomar la palabra, se intercalam trechos de rap e falas de integrantes do Coletivo. Chama a atenção de início a reiteração de um alerta sobre o modo como educamos os nossos filhos e um posicionamento contra o machismo. Segue-se Mc Polyester Kat, integrante do Batallones Femeninos, que o apresenta como "una coletiva de mujeres $^{30 "}$ que se utilizam do hip-hop e da palavra como ferramenta para a denúncia da violência de gênero, do feminicídio no país e que apoiam diversos movimentos sociais. Afirma que decidiram "tomar las palabras" e comparti-las com outras mulheres, como um espaço de autodeterminação. Em seguida, Mc Polyester Kat e MC Luna Negra passam ao rap "Así era ella" e MC Luna Negra comenta que é a história e realidade de muitas mulheres em Ciudad Juárez. Referindo-se à palavra, menciona que, por meio dela, "combatimos todas las violencias en contra nuestras cuerpas ${ }^{31 "}$. No vídeo destacamos como as integrantes do Batallones Femeninos demarcam na sua fala a importância de "tomar la palabra" como estratégia de luta, uma vez que esse enunciado, se torna uma forma de ação, materializando-se nas diversas práticas como as do hip-hop e do rap. Salientamos que podemos contextualizar, no cenário das práticas de resistências empreendidas, a tomada da palavra como uma estratégia de participação e reinvindicação das mulheres na sociedade e, no caso em foco, essa tomada promove outros movimentos discursivos. Sendo assim, aciona igualmente a tomada das tecnologias bem como a dos espaços de comunicação, caso 
das mídias e redes sociais, como cruciais para sua atuação. Por isso, vemos nesses exemplos práticas decoloniais que se disseminam e que acontecem a partir de um lócus de enunciação mais amplificado, de modo que tomar a palavra é, ao mesmo tempo, uma forma de produção discursiva de um coletivo e de uma coletividade. Neste sentido, as diversas maneiras como a palavra é tomada apontam para um lócus de enunciação em permanente reelaboração, de maneira que se torna fundamental rever e reavaliar o papel hegemônico das redes sociais e das mídias e as implicações das práticas visibilizadas e acessadas pelos coletivos, tal como o caso em foco.

\section{Considerações finais}

Ao longo deste trabalho, destacamos, desde uma perspectiva decolonial e em consonância com as epistemologias do Sul, o lócus de enunciação como crucial para a definição de práticas e atitudes decoloniais ao desenhar e projetar outras cartografias no Sul Global no tocante aos sujeitos e às suas práticas de linguagem. Propusemos o lócus de enunciação como um potente dispositivo por materializar e visibilizar uma práxis contrária à ordem hegemônica estabelecida e por se colocar como um espaço de práticas e ações que impulsionam pedagogias decoloniais. Argumentamos sobre a relevância de uma reavaliação da ideia de lócus de enunciação, enquanto um dispositivo por meio do qual os sujeitos subalternizados historicamente ocupam um espaço na discursividade em curso, engendrando tanto um pensar decolonial, quanto um fazer, ou seja, uma práxis decolonial.

Focalizamos as vozes de rappers do coletivo Batallones Femeninos do México, no cenário da fronteira Norte, considerando tanto a localização quanto as tensões geradas na dinâmica Sul Global e Norte Global. Tencionamos mostrar como as rappers mulheres, a partir de seu lócus de enunciação, encontram "seu lugar no mundo", por meio de um conjunto de práticas de linguagem, substancializadas na práxis de uma pedagogia decolonial. A apresentação do material selecionado sugere que essas práticas apontam para uma vitalidade do projeto e da opção decoloniais, para a decolonialidade em curso, tal como a entendemos, atualizando-se na tomada da palavra por agrupamentos juvenis femininos, tal como o caso 
do Coletivo Batallones Femeninos. Essa tomada de palavra se amplifica por meio da apropriação de mídias diversificadas e de tecnologias contemporâneas que contribuem para uma espacialização de discursos de resistência, que, no caso, reafirmam uma pedagogia do cuidado, da existência, da contingência na qual e para o qual a sororidade se torna um elo. Notamos igualmente que essas práticas não se desvinculam das complexidades dos cenários políticos, humanos, sociais, culturais e econômicos em que se originam bem como dos efeitos das colonialidades que permanecem como ressonâncias presentes em territórios e corpos, sobretudo, o das mulheres. Esperamos, desse modo, sinalizar para a existência de uma pedagogia-outra bem como reforçar e reiterar como a práxis decolonial se atualiza por meio do ativismo, dos movimentos sociais e dos coletivos, tal como o caso em tela. Essa complexa e intricada rede de ações e práticas se comunicam, apontando para a convergência de diversas estratégias e metodologias em que a tomada da palavra se amplifica, uma vez que se soma a tomada das tecnologias e dos espaços como as mídias e as redes sociais. Assim sendo, o lócus de enunciação se situa, se corporifica, expandindo-se como um potente dispositivo que visibiliza práticas decoloniais de grupos subalternizados que se enfrentam à lógica da colonialidade, mas o fazem de maneira coletiva, de forma a expandir e conectar-se com outros movimentos.

Acreditamos, portanto, que a mostra de materiais compilados aqui - que deve continuar sendo ampliada como parte de nosso estudo - nos destaca como essa pedagogia decolonial vai sendo desenhada pelos diversos movimentos coletivos, e, em particular, os agrupamentos juvenis femininos, caso dos Batallones Femeninos, e, sendo assim, nos leva a rever como essa produção vem sendo gestada e difundida. Portanto, é de relevância e interesse reconhecê-la enquanto tal e tornala visível, demarcando-a como pedagogia decolonial no Sul Global.

Assim sendo, essa cartografia assume contornos singulares, dadas às suas atualizações espaço-temporais e discursivas, reafirmando o enunciar desde o Sul como via de resistência, existência e insurgência e neste sentido essas vozes são catalizadoras de experiências corporificadas que, pouco a pouco, mostram-se como uma práxis decolonial em 
sua acepção mais ampla no cenário dos feminismos latinoamericanos.

\section{REFERÊNCIAS}

ALCOCER PERULERO, Marisol. ¿Feminicidio de afrodescendientes en México? Lo que no se nombra no existe. Revista sobre acesso à justiça e direitos humanos nas Américas, v. 4, n.1. p. 163-193, jan./jun. 2020. Disponível em: https://periodicos. unb.br/index.php/abya/article/view/32247. Acesso em: 23 fev. 2021.

ANZALDÚA, Gloria (1987). La frontera. Borderlands. La nueva mestiza. Madri: Capitán Swing Livros, 2016.

BALLESTRIN, Luciana. América Latina e o giro decolonial. Revista Brasileira de Ciência Política, n.11, p. 89-117, mai/ago 2013. Disponível em: https://periodicos.unb.br/index.php/rbcp/ article/view/2069/1827. Acesso em: 22 fev. 2021.

BERNARDINO-COSTA, Joaze; GROSFOGUEL, Ramón. Decolonialidade e perspectiva negra. Revista Sociedade e Estado, Brasília, v. 31, n. 1, p. 15-24, abr. 2016. Disponível em: https://periodicos.unb.br/index.php/sociedade/article/ view/6077. Acesso em: 17 fev. 2021.

BERNARDINO-COSTA, Joaze; MALDONADO-TORRES, Nelson; GROSFOGUEL, Ramón. Decolonialidade e pensamento afrodiaspórico. In: BERNARDINO-COSTA, Joaze; MALDONADO-TORRES, Nelson; GROSFOGUEL, Ramón (org.). Decolonialidade e pensamento afrodiaspórico. Belo Horizonte, MG: Autêntica, 2019. p. 6-27.

CASTRO-GÓMEZ, Santiago; GROSFOGUEL, Ramón. Prólogo. Giro decolonial, teoría crítica y pensamiento heterárquico. In: CASTRO-GÓMEZ, Santiago; GROSFOGUEL, Ramón. (org.). El giro decolonial: reflexiones para una diversidad epistémica más allá del capitalismo global. Bogotá: Siglo del Hombre Editores, 2007. p. 9-23.

CONNELL, Raewyn. Southern theory. Cambridge: Polity Press, 2007. 
DÍEZ SALVATERRA, Carmen. Feminismos activistas en el rap latino-americano: Mare (Advertencia Lírika) y Caye Cayejera. Ambigua, Revista de Investigaciones sobre Género y Estudios, $\mathrm{n}$. 3, p. 39-57, 2016. Disponível em: https://rio.upo.es/xmlui/ handle/10433/3520. Acesso em: 09 fev. 2021.

DUSSEL, Enrique. Europa, modernidade e eurocentrismo. In: LANDER, Edgardo (org). A colonialidade do saber: eurocentrismo e ciências sociais. Perspectivas latinoamericanas. Ciudad Autónoma de Buenos Aires, Argentina: Colección Sur Sur, CLACSO, 2005. p. 24-32.

FIGUEIREDO, Ângela; GROSSFOGUEL, Ramón. Racismo à brasileira ou racismo sem racistas: colonialidade do poder e a negação do racismo no espaço universitário. Sociedade e Cultura, v. 12, n. 2, p. 223-234, jul./dez. 2010. Disponível em: https://doi. org/10.5216/sec.v12i2.9096. Acesso em: 05 out. 2020.

FANON, Frantz. Black Skin, White Mask. New York: GroveWeidenfeld, 1967.

FISCALÍA GENERAL DEL ESTADO DE CHIHUAHUA. Missión y visión. Disponível em: http://fiscalia.chihuahua. gob.mx/inicio/?page_id=35. Acesso em: 27 mai. 2021.

FREIRE, Paulo. "Astutos e inocentes". In: FREIRE, Paulo. Conscientização: teoria e prática da libertação. Uma introdução ao pensamento de Paulo Freire. São Paulo: Cortez \& Moraes, 1979.

GARCÍA AMARAL, María Luisa. Ciudades fronterizas del Norte de México. In: Anales de Geografía de la Universidad Complutense, v. 27, n. 2, p. 41-57, ene. 2008. Disponível em: https://revistas.ucm.es/index.php/AGUC/article/view/ AGUC0707220041A. Acesso em: 12 fev. 2021.

GÓMEZ-QUINTERO, Juan D. La colonialidad del ser y del saber: la mitologización del desarrollo en América Latina. El Ágora USB, v. 10, n. 1, p. 87-105, ene/jun 2010. Disponível em: https://revistas.usb.edu.co/index.php/Agora/article/view/366. Acesso em: 22 fev. 2021.

GROSFOGUEL, Ramón. La descolonización de la economía y los estudios postcoloniales: Transmodernidad, pensamiento 
fronterizo y colonialidad global. Tabula Rasa, Bogotá, n. 4, p. 17-48, ene/jun 2006. Disponível em: https://www.revistatabularasa. org/numero04/la-descolonizacion-de-la-economia-politica-ylos-estudios-postcoloniales-transmodernidad-pensamientofronterizo-y-colonialidad-global/. Acesso em: 22 fev. 2021.

GROSFOGUEL, Ramón. Para descolonizar os estudos da economia política e os estudos pós-coloniais: transmodernidade, pensamento de fronteira e colonialidade global. In: SANTOS, Boaventura de Sousa; MENESES, Maria Paula. (org.). Epistemologias do Sul. Coimbra: Almedina, 2010. p. 383-417.

GUILLÉN LÓPEZ, Tonatiuh. Frontera norte: los contrastes de la calidad de vida. Revista Mexicana de Política Exterior, n. 81, p.10-32, jul/oct 2007. Disponível em: https://revistadigital.sre. gob.mx/index.php/numeros-anteriores/118-rmpe81. Acesso em: 22 fev. 2021.

LÓPEZ, Marco Antonio. III. Un año sin Isabel: la pandemia no detiene a las mujeres que luchan. Yo Ciudadano. Investigación y análisis ciudadanos. Chihuahua, 30, jan. 2021. Investigaciones. Disponível em: https://yociudadano.com.mx/investigaciones/ domar-a-la-pandemia/iii-una-ano-sin-isabel-la-pandemia-nodetiene-a-las-mujeres-que-luchan. Acesso em: 27 mai. 2021.

MALDONADO-TORRES, Nelson. Analítica da colonialidade e da decolonialidade: algumas dimensões básicas. In: BERNARDINO-COSTA, Joaze; MALDONADO-TORRES, Nelson; GROSFOGUEL, Ramón (org.). Decolonialidade e pensamento afrodiaspórico. Belo Horizonte, MG: Autêntica, 2019. p. $27-54$.

MALDONADO-TORRES, Nelson. A modo de comentário inicial. In: WALSH, Catherine (org). Pedagogias decoloniales: Prácticas insurgentes de resistir, (re)existir y (re)vivir. Tomo I. Quito: Ediciones Abya-Yala, 2013. p.11-14.

MEYRA, Clara G. Segura. (2016). Vivas nos queremos: Las calles en México se pintan de violeta. Disponível em: http://rosalux. org.mx/articulo/vivas-nos-queremos-las-calles-en-mexico-sepintan-de-violeta. Acesso em: 02 mar. 2021. 
MENESES, Maria Paula. Introdução. Epistemologias do Sul. Revista Crítica de Ciências Sociais, n. 80, 2008. Disponível em: http:// journals.openedition.org/rccs/689. Acesso em: 07 jan. 2021.

MIGNOLO, Walter. A colonialidade de cabo a rabo: o hemisfério ocidental no horizonte conceitual da modernidade. In: LANDER, Edgardo (org). A colonialidade do saber: eurocentrismo e ciências sociais. Perspectivas latinoamericanas. Ciudad Autónoma de Buenos Aires, Argentina: Colección Sur Sur, CLACSO, 2005. p. 33-49.

MIGNOLO, Walter. The darker side of Western Modernity: global futures, decolonial options. Durham/London: Duke University Press, 2011.

MOTA NETO, João Colares; STRECK, Danilo. Fontes da educação popular na América Latina: contribuições para uma genealogia de um pensar pedagógico decolonial. Educar em Revista, Curitiba, Brasil, v. 35, n. 78, p. 207-223, nov./dez. 2019. Disponível em: https://revistas.ufpr.br/educar/article/ view/65353. Acesso em: 01 fev. 2021.

MOTA NETO, João Colares; STRECK, Danilo. A geopolítica do conhecimento e a diferença colonial. Revista Lusófona de Educação, n.48, p. 187-224, 2020.

OJEDA DE LA PEÑA, Norma. Las uniones libres o consensuales en la frontera norte de México. Estudios demográficos y urbanos, v. 28, n. 3, p. 645-679, 2013. Disponível em: https:// estudiosdemograficosyurbanos.colmex.mx/index.php/edu/ article/view/1449/1442. Acesso em: 19 fev. 2021.

ONU Mulheres, Diretrizes nacionais feminicídio: Investigar, processar e julgar Com perspectiva de gênero as mortes violentas de mulheres. Curadoria Enap. Disponível em: https:// exposicao.enap.gov.br/items/show/267. Acesso em: 23 fev. 2021.

QUIJANO, Aníbal. Colonialidade do poder, eurocentrismo e América Latina. In: LANDER, Edgardo (org.). A colonialidade do saber: eurocentrismo e ciências sociais. Buenos Aires: CLACSO, 2005. p. 227-278. 
QUIROZ-PÉREZ, Lissell. Del centro a las márgenes. Los feminismos de Perú y México de los 70 a la actualidad. Amerika, n. 16, 2017. Disponível em: http://journals.openedition.org/ amerika/8056. DOI: https://doi.org/10.4000/amerika.8056. Acesso em: 25 fev.2021.

RIBEIRO, Djamila. Lugar de fala. São Paulo: Pólen, 2019.

SANTOS, Boaventura de Sousa; MENESES, Maria Paula (org.). Epistemologias do Sul. São Paulo: Cortez, 2010.

SANTOS, Boaventura de Sousa. Toward a New Common Sense: Law, Science and Politics in the Paradigmatic Transition. New York: Routledge, 1995.

SANTOS, Boaventura de Sousa. Para além do Pensamento Abissal: das linhas globais a uma ecologia de saberes. Revista Crítica de Ciências Sociais, n. 78, p.3-46, 2007. Disponível em: https://journals.openedition.org/rccs/753. Acesso em: 22 fev. 2021.

SANTOS, Boaventura de Sousa. Para além do pensamento abissal: das linhas globais a uma ecologia de saberes. In: SANTOS, Boaventura de Sousa; MENEZES, Maria Paula (org.). Epistemologias do Sul, p. 23-72. Coimbra: Edições Almedina, 2010.

SANTOS, Boaventura deSousa. Percursos para as epistemologias do Sul. In: O fim do império cognitivo. A afirmação das epistemologias do Sul. Belo Horizonte: Autêntica, 2019.

SILVA LODOÑO, Diana Alejandra. "Somos las vivas de Juárez": hip-hop femenino en Ciudad Juárez. Revista Mexicana de Sociología, v. 79, n.1, p. 147-174, ene/mar 2017. Disponível em: http://revistamexicanadesociologia.unam.mx/index.php/rms/ article/view/57656/51113. Acesso em: 10 fev. 2021.

VAZQUEZ, Adolfo Sánchez. Filosofia da Práxis. Rio de Janeiro: Editora Paz e Terra, 1977.

WALSH, Catherine. Introducción - lo pedagógico y lo decolonial: entretejiendo caminos. In: WALSH, Catherine (org.), Tomo I: pedagogías decoloniales: prácticas insurgentes de 
resistir, (re)existir y (re)viver. Quito-Ecuador: Ediciones AbyaYala, Serie Pensamiento Decolonial, 2013. p. 23-68.

ZÚÑIGA GONZÁLEZ, Víctor Aurelio. La diversidad de las sociedades fronterizas México/Estados Unidos. Frontera Norte, v. 23, n. 45, p. 287- 295, ene/ jun 2011. Disponível em: https:// fronteranorte.colef.mx/index.php/fronteranorte/article/ view/845. Acesso em: 22 fev. 2021.

\section{ABSTRACT \\ Locus of enunciation and mexican collective Batallones Femeninos: mapping a decolonial pedagogy in the Global South}

In this text, from a decolonial perspective (BALLESTRIN, 2013; BERNARDINOCOSTA; MALDONADO TORRES; GROSFOGUEL 2019) and according to the epistemologies of the South (SANTOS, 2019; 2010; 1995; MENESES, 2008), we defend the locus of enunciation (BERNARDINO-COSTA; GROSFOGUEL, 2016; FIGUEIREDO; GROSFOGUEL, 2010; GROSFOGUEL, 2006; 2010) as crucial for the definition of decolonial practices and attitudes. In this sense, we argue that the locus of enunciation materializes a praxis contrary to the established hegemonic order, becoming a space for practices and actions that boost decolonial pedagogies (WALSH, 2013; MOTA NETO; STRECK, 2019). First, we present our understanding of the locus of enunciation, emphasizing it as a catalyst and intensifier of speech and language practices that reconfigure the enunciative space of the Global South with reverberations in the form of decolonial practices. Subsequently, we made more visible the language practices projected from the enunciative locus, focusing on Mexico's northern border scenario. In particular, the collective Batallones Femeninos that, through a set of language practices disseminated in 
different media, face multiple coloniality of being, power, and knowledge (QUIJANO, 2005).

Keywords: Decoloniality. Decolonial pedagogy. Locus of enunciation. North border. Feminisms.

Lívia Márcia Tiba Rádis Baptista é Mestra em Letras e em Educação pela USP. Doutora em Linguística pelo IEL, UNICAMP. Foi professora efetiva da Universidade Federal do Ceará e atualmente da Universidade Federal da Bahia. Realizou estância pósdoutoral no México, na Universidade Autônoma da Baixa Califórnia e na Universidade Autônoma Benito Juárez de Oaxaca e na Universidade Pompeu Fabra de Barcelona, Espanha. Seus temas de interesse de pesquisa no campo aplicado envolvem decolonialidades, educação e estudos da linguagem, com ênfase no espanhol. Líder do Grupo de pesquisa do CNPq DECOLIDE (Decolonialidade, Linguagem, Identidade e Educação). 